Сократительная активность детрузора крыс с инфравезикальной обструкцией после введения криоэкстракта спинальных ганглиев и биологически активных продуктов культуры мантийных глиоцитов В.Ю. Глоба, Т.П. Бондаренко, С.Г. Али, Г.А. Божок, Е.И. Легач Институт проблем криобиологии и криомедицины НАН Украины, г. Харьков

\title{
Contractile Activity of Detrusor of Rats with Infravesical Obstruction After Introduced Cryoextract of Spinal Ganglia and Biologically Active Products of Mantle Gliocyte Culture
}

\author{
V.Yu. Globa, T.P. Bondarenko, S.G. Ali, G.A. Bozhok, E.I. Legach \\ Institute for Problems of Cryobiology and Cryomedicine of the National Academy of Sciences of Ukraine, Kharkiv
}

Инфравезикальная обструкция (ИВО) приводит к повреждению стенки мочевого пузыря (МП). Для коррекции патологических изменений функции МП возможно системное введение нейротрофических факторов (НФ) [L. Gardell и соавт., 2003].

Цель работы - изучение сократительной активности детрузора крыс с инфравезикальной обструкцией после введения криоэкстракта спинальных ганглиев или кондиционированных сред, полученных от нативной и криоконсервированной культур мантийных глиоцитов.

Все манипуляции с животными проводились в соответствии с положениями «Европейской конвенции о защите позвоночных животных, используемых для экспериментальных или иных научных целей» (Страсбург, 1986). Криоэкстракт получали из спинальных ганглиев (СГ) половозрелых крыс путем 3-кратного замораживания в жидком азоте с последующей гомогенизацией и центрифугированием. Культуру мантийных глиоцитов (МГ) получали из СГ неонатальных поросят. Клетки в концентрации $5 \times 10^{5}$ кл/мл высевали на чашки Петри («Orange Scientific», Бельгия) и культивировали 20 суток при $37^{\circ} \mathrm{C}, 5 \% \mathrm{CO}_{2}$. Часть культуры МГ криоконсервировали с 10\% ДМСӦ со скоростью охлаждения 1 град/мин до $-40^{\circ} \mathrm{C}$ при дальнейшем погружении в жидкий азот. Клетки после отогрева и отмывания от ДМСО культивировали по вышеописанной методике. Базовая среда культивирования включала $\alpha$-МЕМ, $10 \%$-ю фетальную телячью сыворотку («BioSera», Франция) и антибиотики. Через 20 суток собирали кондиционированную среду (КС) и аликвотировали по 0,2 мл. Инфравезикальную обструкцию моделировали на 6-месячных белых беспородных крысах-самках лигатурным методом. Через 1,5 месяца лигатуру снимали и животным внутрибрюшинно в течение 10 дней вводили 0,2 мл биологически активных веществ. Сократительную активность детрузора (САД) исследовали на изолированных полосках MП [F.A. Kullmann и соавт., 2014]. Животных разделили на группы: 1 - введение криоэкстракта СГ; 2 - введение базовой среды культивирования; 3 - введение кондиционированной среды от нативных МГ; 4 - введение кондиционированной среды от криоконсервированных МГ; 5 - без лечения; 6 - контроль.

У животных групп 1, 3, 4 САД увеличилась на 92, 66 и $177 \%$ соответственно по сравнению с контролем. В группе 4 САД была больше на 31,5 и 40\% по сравнению с группами 1 и 3.

Результаты эксперимента свидетельствуют о возможности НФ восстанавливать САД. Позитивное влияние криоэкстракта СГ и КС из криоконсервированных МГ указывает на возможность их применения для коррекции функциональных нарушений МП при ИВО.
The infravesical obstruction (IVO) causes damages in the wall of urinary bladder (UB). Pathological changes in UB functions may be repaired with systemic administration of neurotrophic factors (NF).

This research aim was to study the detrusor contractile activity of rats with infravesical obstruction after administering the cryoextract of spinal ganglia or conditioned media, procured from native and cryopreserved mantle gliocyte cultures.

All the manipulations with animals were done in accordance with the statements of European Convention for the Protection of Vertebrate Animals Used for Experimental and Other Scientific Purposes (Strasburg, 1986). The cryoextract was procured from the spinal ganglia (SG) of mature rats by threefold freezing in liquid nitrogen, followed by homogenization and centrifugation. The mantle gliocyte (MG) culture was derived from the SG of neonatal piglets. Cells were plated at a concentration of $5 \times$ $10^{5}$ cells / $\mathrm{ml}$ in Petri dishes (Orange Scientific, Belgium) and cultured for 20 days at $37^{\circ} \mathrm{C}, 5 \% \mathrm{CO}$. A part of $\mathrm{MG}$ culture was cryopreserved with $10 \%$ DMSO with $1{ }^{\circ} \mathrm{C} / \mathrm{min}$ cooling rate down to $-40^{\circ} \mathrm{C}$, followed by immersion into liquid nitrogen. After warming and DMSO removal, the cells were cultured as described above. The baseline culture medium included $\alpha$-MEM, $10 \%$ fetal bovine serum and antibiotics. Twenty days later, the conditioned medium (CM) was collected and aliquoted by $0.2 \mathrm{ml}$. The IVO was simulated in 6-month-old white outbred female rats using the ligature method. The ligature was removed 1.5 months later, and the animals received intraperitoneally $0.2 \mathrm{ml}$ of biologically active substances for 10 days. The contractile activity of detrusor (CAD) was examined using the isolated strips of UB [F.A. Kullmann et al., 2014]. The animals were divided into the following groups: the group 1 made the animals with administered SG cryoextract; the group 2 comprised those with administered baseline culture medium; in the group 3 were animals with administered $\mathrm{CM}$ from native $\mathrm{MG}$; the group 4 consisted of those with administered CM from cryopreserved $\mathrm{MG}$; not treated animal and the intact control made the groups 5 and 6, respectively.

In the groups 1,3 and 4 animals the CAD increased by 92,66 and $177 \%$, respectively, if compared with the intact control. In the group 4 , the CAD was higher by 31.5 and $40 \%$ as compared with the groups 1 and 3 .

Our findings testify to the capability of NF to restore the CAD. The positive effect of applying SG cryoextract and $\mathrm{CM}$ derived from cryopreserved MG shows them to be promising for correcting UB functional impairments in IVO. 